\title{
The phyllosphere microbiome and its potential application in horticultural crops. A review
}

\section{El microbioma de la filosfera y su aplicación potencial en la horticultura. Una breve revisión}
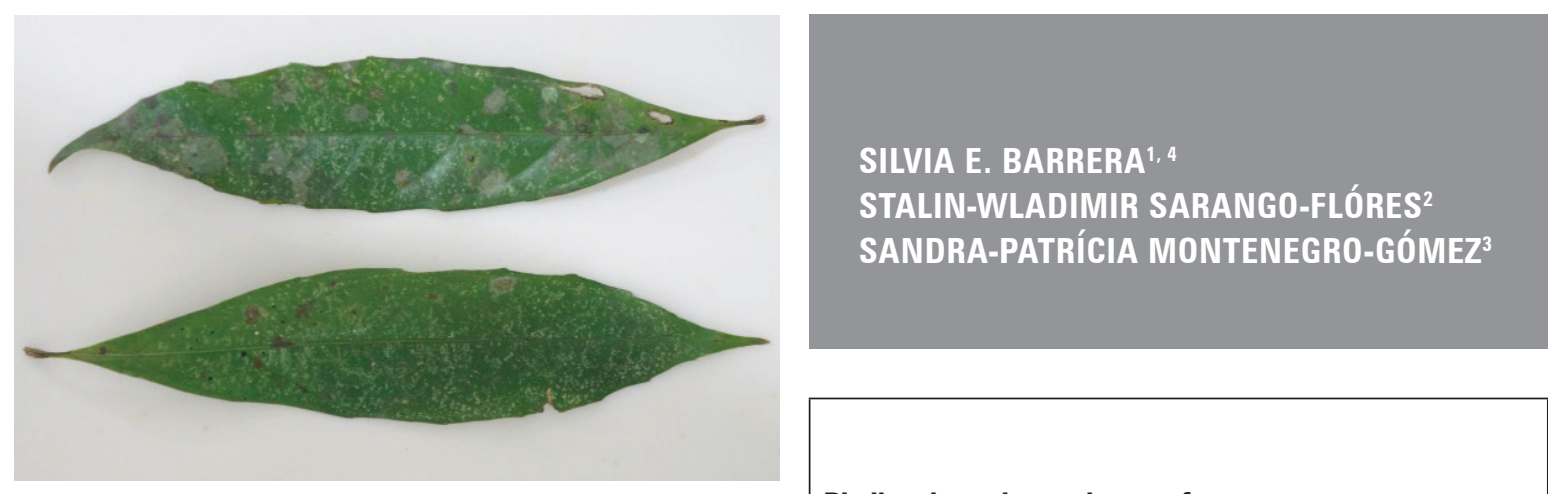

SILVIA E. BARRERA ${ }^{1,4}$

STALIN-WLADIMIR SARANGO-FLÓRES²

SANDRA-PATRÍCIA MONTENEGRO-GÓMEZ

Phyllosphere, host, plant surface.

Photo: S.E. Barrera

\begin{abstract}
Microorganisms are essential for life on Earth. They are found in different environments and conditions, such as $\mathrm{pH}$, temperature, pressure, and humidity, etc. In natural and agricultural ecosystems, nutrient cycling and plant protection are important roles played by microorganisms associated with plant species. However, the mechanisms to colonize those environments are not fully understood. This mini-review describes bacterial communities associated with the phyllosphere and an agricultural approach for potential applications. In the context of foodborne illnesses and losses in agricultural production, important issues have arisen because of pathogen attacks. On the other hand, the use of beneficial microorganisms in agriculture is an alternative for improving plant growth, health and production. In this sense, growth promoting bacteria and biocontrol agents isolated from the phyllosphere of several plant species have been less exploited than those from the soil or rhizosphere. However, the treatment of some plant diseases, reduction in pathogen incidence and nitrogen fixation in natural and agricultural systems are successful examples. In the context of food safety, a better understanding of how the indigenous phyllosphere microbiota enable plants to protect themselves against pathogens and to acquire nutrients is expected to prove its importance in the agricultural field. Microbial sources can be managed to reduce the use of chemical products and could be used as an alternative of agronomical applications for improving agroecosystem productivity.
\end{abstract}

Additional key words: epiphytic community; plant health and growth; ecosystem productivity; biocontrol.

Servifran Bioingetech, Investigación, Giron (Colombia). Barrera, S.E.: 0000-0001-6834-3585

Leiden University, Institute of Biology, Leiden, The Netherlands. ORCID Sarango-Flóres, S.-W.: 0000-0003-2000-7261

3 Universidad Nacional Abierta y a Distancia, Centro de Investigación de Agricultura y Biotecnología-CIAB, Dosquebradas (Colombia). ORCID Montenegro-Gómez, S.-P.: 0000-0003-0035-0089

4 Corresponding autor. silviaebarrerab@gmail.com 


\section{RESUMEN}

Los microorganismos son esenciales para la vida en la tierra. Ellos se encuentran colonizando diferentes ambientes y en diferentes condiciones de $\mathrm{pH}$, temperatura, humedad, etc. En ecosistemas naturales y agrícolas, el ciclado de nutrientes y la protección de la planta, son funciones importantes desempeñadas por los microorganismos asociados a las especies vegetales. Sin embargo, los mecanismos para colonizar esos ambientes no son completamente entendidos. En esta corta revisión se describen las comunidades bacterianas asociadas a la filosfera, con un enfoque agrícola de sus aplicaciones potenciales en esta área, relacionadas con nutrición y control biológico. En el contexto de alimentos contaminados y pérdidas en la producción agrícola, han surgido graves problemas debido al ataque de patógenos. Por otra parte, es claro que el uso de microorganismos benéficos en la agricultura es considerado como alternativa para mejorar el crecimiento, la producción y la salud de la planta. En este sentido, bacterias promotoras de crecimiento vegetal y agentes de biocontrol, aislados de la filosfera de diferentes especies vegetales han sido menos explotados que los microorganismos de la rizosfera. No obstante, el tratamiento de enfermedades, reducción de la incidencia de patógenos y la fijación de nitrógeno, en sistemas naturales y agrícolas, son ejemplos exitosos. En el contexto de seguridad alimentaria, se espera entender mejor cómo la microbiota nativa de la filosfera ayuda a la planta a protegerse contra patógenos y a la adquisición de nutrientes, para demostrar su importancia en el área agrícola. Esto indica que, fuentes microbianas pueden ser usadas para reducir el uso de productos químicos y aplicarlas como una alternativa agronómica para mejorar la productividad de los agroecosistemas.

Palabras clave adicionales: comunidad epifítica; crecimiento y salud vegetal; productividad del ecosistema; biocontrol

Received for publication: 08-09-2018 Accepted for publication: 29-11-2019

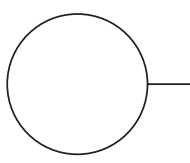

INTRODUCTION

Microorganisms are found in various environments, such as water, air, soil, plant surfaces, animals, food, the human body and buildings (Prussin and Marr, 2015; Rosenberg and Zilber-Rosenberg, 2016). Some of them live in symbiosis with plants or animals, while others have a free-living lifestyle (Dutta and Paul, 2012). Symbiotic associations between plants and soil microorganisms such as arbuscular mycorrhizal fungi (Igiehon and Babalola, 2017), nitrogenbacteria in legumes (Mus et al., 2016) or the water fern Azolla and the cyanobacterium Anabaena azollae (Bhuvaneshwari and Singh, 2015) have been amply studied because of the positive outcomes of these associations in natural and agricultural systems. However, microorganisms associated with aerial plant surfaces could have positive effects, as do soil microorganisms, and could be used as sources of inoculum (Andreote et al., 2014).

The phyllosphere is the aerial portion of plants, mainly the leaf surface, which is an environment widely inhabited by bacteria that form biofilms or larger aggregates (Lindow and Brandl, 2003; Baldoto and Olivares, 2008). Biofilm formations, extracellular polymeric substances (EPS) and enzyme production protect the epiphytic microbial community from a stressful environment (Remus-Emsermann and Vorholt, 2014; Müller et al., 2016a). Despite the phyllosphere being low in nutrients, plants release an adequate concentration to support large microbial communities (Mercier and Lindow, 2000), and microbial communities develop mechanisms to acquire nutrients (Delmmote et al., 2009; Bulgarelli et al., 2013).

A core bacterial microbiome composed of Proteobacteria, Actinobacteria, Bacteroidetes and Firmicutes phyla has been found in different plant species, in both forests and agricultural ecosystems (Redford et al., 2010; Vorholt, 2012; Rastogi et al., 2012; Bulgarelli et al., 2013; Kembel et al., 2014; Lambais et al., 2014; Laforest-Lapoint et al., 2016, Müller et al., 2016b). However, the bacterial abundance depends on several factors, such as plant species, geographical distance and environmental conditions (RemusEmsermann and Vorholt, 2014; Copeland et al., 2015; Laforest-Lapoint et al., 2016). This suggests that some small bacterial groups are highly efficient at colonizing and surviving in the phyllosphere (Griffin and Carson, 2015). At the same time, bacterial communities share a core of proteins on different plant hosts, suggesting similar mechanisms for adaptation and survival on different plant species (Remus-Emsermann and Vorholt, 2014; Lambais et al., 2017). 
In the context of food safety, a better understanding of how the natural microbiota enables plants to protect themselves against pathogens and/or to acquire nutrients will be valuable in agricultural production (Rastogi et al., 2013). This suggests that microbial sources can be managed as an alternative of agronomical applications to improve the productivity of the agricultural ecosystem (Peñuelas and Terradas, 2014). Likewise, agroecosystems are subject to intense chemical management; therefore, the microbial diversity associated with leaf surfaces can have variations across space, time, season and environmental conditions (Rastogi et al., 2013).

Nowadays, we have to deal with difficult challenges, such as the concern for foodborne illnesses and agricultural production losses from pathogen attacks. In Colombia, a few studies have been done to identify microbial communities associated with the phyllosphere (Toloza and Lizarazo, 2014). These studies have focused mainly on the characterization of pathogenic microorganisms that inhabit the phyllosphere (Restrepo et al., 2000; Marín et al., 2003), meanwhile other studies have focused on biological control (Salazar et al., 2006; Medina et al., 2009; Cruz-Martín et al., 2016) and taxonomical profiles of bacterial communities (Ruíz-Pérez et al., 2016). Although there is increasing evidence that beneficial bacteria may stimulate plant growth and health (Vogel et al., 2016), microbial community dynamics at the community level and their interactions with the plant host are still unknown (Schlechter et al., 2019). This mini-review provides an agricultural approach on the potential applications of microbial communities associated with the phyllosphere in horticulture crops through microbial bioprospecting. First, phyllospere generalities are stated, such as habitat for bacteria and fungi. Second, abiotic and biotic factors affecting the microbial community associated with the phyllosphere are also described. Subsequently, references are made about potential applications in agriculture, focusing on nutrition and biological control. Patent processes found in the Patentscope database from studies on the phyllosphere microbiome are shown. This information shows examples of bioprospecting bacteria with biotechnological potential. Finally, several examples of studies carried out in Colombia on horticultural plants are presented. The information was accessed with keywords such as: phyllosphere, microbiome, agriculture, bioprospecting, biotechnology, microbial communities associated with the phyllosphere, in Google Scholar and Scopus.

\section{THE PHYLLOSPHERE IS A MICROBIAL HABITAT}

The phyllosphere is the portion found in upper and lower leaf surfaces (Fig. 1), covering an area of $640 \cdot 10^{8}$ $\mathrm{km}^{2}$ on Earth (Lindow and Brandl, 2003; Peñuelas and Terradas, 2014). As well as bacteria, this environment is colonized by other microorganisms such as archaea, filamentous fungi, lichens, bryophytes, yeast and protozoa, all living in limited water and nutrients conditions (Vorholt, 2012; Rastogi et al., 2013; Müller and Ruppel, 2014).

The leaf surface is an oligotrophic environment that obligates microorganisms to compete for nutrients and space (Delmotte et al., 2009; Bringel and Couée, 2015). Carter et al. (2012) suggested that competition for nutrients, essentially carbon and nitrogen, is the first mechanism of interaction among microorganisms that colonize a phyllosphere. Leaf nitrogen content is correlated with the phyllosphere community structure in several plants (Kembel et al., 2014; Kembel and Mueller, 2014; Laforest-Lapoint et al., 2016), while carbohydrates produced by photosynthesis are exudated on the leaf surface along with methanol, volatile organic compounds (Vacher et al., 2016), amino acids, organic acids, inorganic compounds, and various salts (Mercier and Lindow, 2000). Leaf chemical composition and morphology affect the distribution of microorganisms across leaves (RemusEmsermann and Vorhold, 2014). For instance, the leaf cuticle is a substrate composed of polymeric and soluble lipids that is difficult to metabolize by microorganisms, but could be involved in phyllosphere colonization (Morris, 2002). Chemical, structural and physiological properties related to a spectrum running from quick to slow return on investments of nutrients and dry mass in leaves, "The leaf economics spectrum" (Wright et al., 2004) could explain the variation in microbial community structures, according to acquisitive or retentive resource strategy (Friesen et al., 2011).

Undoubtedly, bacteria are the most abundant microbial group in the phyllosphere followed by fungi (Lindow and Brandl, 2003). The density of bacteria is from $10^{6}$ to $10^{7}$ cells per square centimeter of leaf tissue (Vorholt, 2012; Rastogi et al., 2013). Despite bacteria playing essential roles in nutrient cycling (Vacher et al., 2016), plant protection against pollutants and pesticides (Müller and Ruppel, 2014) and improving plant development (Delmotte et al., 2009), little is known about bacterial diversity and 


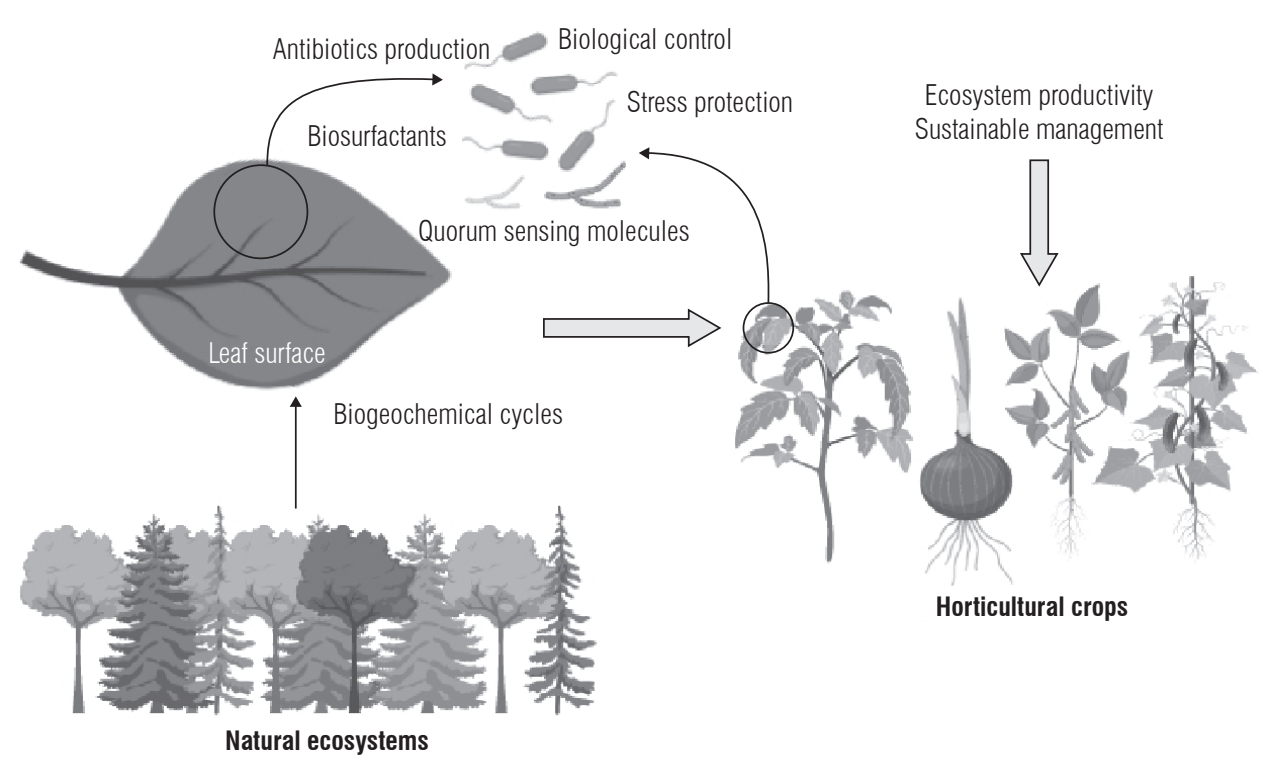

Figure 1. Scheme of the leaf surface colonized by several bacteria and fungi genera detected in the phyllosphere, along with ecological functions and applications.

biogeography in this environment since most of the bacteria detected in the phyllosphere have not yet been described (Lambais et al., 2014). Filamentous fungi and yeast communities associated with the phyllosphere are also important components involved in nutrient cycling (Vacher et al., 2016) and plant protection (Arnold et al., 2003). Jumpponen and Jones (2009) suggested that plant exudates are decomposed by epiphytic fungi; however, the fungi colonization in phyllosphere has not been well characterized (Kembel and Mueller, 2014).

The assemblage of microbial communities on the phyllosphere of distinct plant species could be modulated by the interaction of several environmental factors (Andreote et al., 2014). Similarly, interaction between microorganisms and their hosts drives the microbiota assembly (Müller et al., 2016a). On the other hand, colonizing microorganisms of the phyllosphere not only can come from the air but also can come from an early recruitment on seeds, soil or other plants (Knief et al., 2010; Copeland et al., 2015; Lemanceau et al., 2017).

The microbial community in the phyllosphere presents high richness (Kim et al., 2012; Kembel et al., 2014) but low diversity when compared with the rhizosphere (Delmotte et al., 2009; Knief et al., 2012). The classes Alphaproteobacteria and Gammaproteoacteria are the most abundant groups detected in several plant species (Fürnkranz et al., 2008; Kim et al., 2012; Lambais et al., 2006, 2014, 2017). In tropical rainforests, Sphingomonas (Alphaproteobacteria) and Pseudomonas (Gammaproteobacteria) have been reported as the dominant bacterial genera (Lambais et al., 2006, 2014; Bodenhausen et al., 2013). In several crops such as rice, bean, cucumber, soybean, lettuce maize clover and Arabidopsis, Sphingomonas, Methylobacterium (Alphaproteobacteria) and Pseudomonas (Gammaproteobacteria) are the most abundant genera (Delmotte et al., 2009; Knief et al., 2012; Rastogi et al., 2013; Müller et al., 2016b). The dominance of Sphingomonas spp. and Methylobacterium spp. can be explained by the presence of carbon resources that they consume (Remus-Emsermann and Vorholt, 2014), while Pseudomonas spp. can be explained by its mobility towards nutrient sites on the leaf, with significant advantages over immobile bacteria (Vorholt, 2012). The phototrophic lifestyle, as part of their metabolic requirements, offers bacteria an ecological advantage to survive in the phyllosphere. For instance, the presence of anoxygenic phototrophic bacteria and rhodopsins in clover, Arabidopsis and Tamarisk phyllosphere (Atamna-Ismaeel et al., 2012a, 2012b; Finkel et al., 2016).

With respect to fungi phyllosphere community, it has been linked to pathogens, saprotrophs and lichenized fungi (Jumpponen and Jones, 2009). Filamentous fungi and yeast, such as Ascomycota and Basidiomycota, 
are reported as dominant groups in the phyllosphere (Cordier, 2012). For example, Hypocrea, Aureobasidium and Cryptococcus genera were reported as dominant in the tomato phyllosphere (Ottesen et al., 2013).

\section{FACTORS AFFECTING BACTERIAL COMMUNITY IN PHYLLOSPHERE}

The phyllosphere is a hostile and complex environment influenced by abiotic and biotic factors, including plant metabolism, UV radiation (Vorholt 2012), temperature (Delmotte et al., 2009), carbohydrate levels (Hunter et al., 2010), elevated $\mathrm{CO}_{2}$ (Ren et al., 2014), plant traits, seasonal leaf changes, position (Copeland et al., 2015; Laforest-Lapoint et al., 2016) and the chemistry of waxy cuticle covering the leaf (Bodenhausen et al., 2014; Remus-Emsermann and Vorholt, 2014). However, how these factors affect the microbial communities in the phyllosphere is not fully understood.

Temperature is greatly variable on leaf surface over time and space (Chelle, 2005), even in the same plant or leaf (Vacher et al., 2016). Changes in phyllosphere communities are related to rainfall events (Copeland et al., 2015). Water films cover leaf surfaces, causing chemical reactions between water and compounds or molecules deposited on the leaves (Vacher et al., 2016), which modify the water $\mathrm{pH}$ and affect the nutrient availability for microorganisms (Morris, 2002).

Leaves are exposed to large amounts of sunlight, causing DNA-damage (Remus-Emsermann and Vorholt, 2014); therefore, adaptation to and protection from stressful conditions from UV radiation are related to the detection of DNA protection proteins (Delmotte et al., 2009). Furthermore, microbial communities in the phyllosphere can be highly variable depending on the season (Jackson and Denney, 2011; Williams et al., 2013), while other plants have similar bacterial communities all year round (Redford and Fierer, 2009). Changes in plant metabolism caused by abiotic factors indirect affect the phyllosphere microbiome as well (Turner et al., 2013).

Plant genotype may also drive the assembling of bacterial communities in the phyllosphere (Redford et al., 2010; Rastogi et al., 2013). Possible mechanisms used by plants to assemble their microbial community have not yet been elucidated, but interaction plant genotype-microbial community (Kim et al., 2012) and identifications of essential genes in the plant and the microorganisms are important factors to manipulate the leaf microbiota and to improve plant protection (Müller and Ruppel, 2014). The selection of different bacterial consortia by plants (Lambais et al., 2006) occurs by compounds exudated on the leaf surfaces (Yadav et al., 2011).

For instance, Beattie and Lindow (1999) reported indol-acetic acid and extracellular polysaccharides as compounds produced by phyllosphere bacteria to modify the environment, improving nutrient availability and increasing bacterial community survival on the leaf surface.

Changes in the composition of bacterial communities associated with the phyllosphere might occur because of geographical distance (Bokulich et al., 2014). Redford et al. (2010) reported on bacterial communities that were highly similar in plants phylogenetically, suggesting evolutive history between plants and bacteria. However, different plant species from a single location can assemble bacterial communities that are highly similar, as influenced by local conditions (Whipps et al., 2008; Finkel et al., 2011). Furthermore, differences have also been observed in bacterial communities associated with individuals of the same plant species but geographically distant, which indicates that differences could arise from distinct climatic conditions or different leaf traits (Redford and Fierer, 2009; Finkel et al., 2012). The composition and abundance of the microbial community associated with leaf surfaces are not enough to understand the driving factors affecting the phyllosphere microbiome because of leaf surface heterogeneity (RemusEmsermann and Schlechter, 2018). Therefore, spatial scale analysis could be used to explain how ecological microbial interactions could contribute to the identification of key organisms associated with plant health and function (Berry and Widder, 2014; Poudel et al., 2016).

\section{POTENTIAL AGRICULTURAL APPLICATIONS}

Communication (volatile organic compounds), protection (antibiosis), nutrient cycling (N, C), and plant growth (phytohormones) are essential ecosystem services provided by the phyllosphere microbial communities (Tab. 1) (Morris, 2002; Vacher et al., 2016). Manipulating the foliar microbiome to reduce the use of synthetic pesticides and inorganic fertilizers is a beneficial activity that promotes plant growth and health (Adesemoye and Kloepper, 2009). 
Table 1. Ecosystem functions of microorganisms in the phyllosphere.

\begin{tabular}{|l|l|l|l|}
\hline \multicolumn{1}{|c|}{ Microbial function } & \multicolumn{1}{c|}{ Plant benefits } & \multicolumn{1}{c|}{ Source } \\
\hline Nitrogen fixation & $\begin{array}{l}\text { Foliar nitrogen content } \\
\text { Plant growth }\end{array}$ & Productivity, nutrient acquisition & Fürnkranz et al. (2008) \\
\hline Phytohormones production & Plant growth & Biomass production & Almethyeb et al. (2013) \\
\hline Pathogen suppression & Protection, plant health & Productivity & Wei et al. (2016) \\
\hline Antimicrobial activity & Protection, plant health & Productivity & Bulgarelli et al. (2013) \\
\hline Induced systemic resistance & Protection, plant health & Productivity & Bulgarelli et al. (2013) \\
\hline Phylloremediation & Detoxification & Atmospheric depollution & Bringel and Couée (2015) \\
\hline Probiotic agents & Reduction chemical products & Sustainable agriculture & Berlec (2012) \\
\hline
\end{tabular}

\section{Possible nutritional inputs through the phyllosphere}

Microbial communities mediate the nutrient exchanges occurring between the phyllosphere and the atmospheric interface (Abril et al., 2005). In tropical forests and agriculture or silviculture systems, foliar diazotrophs contribute to nitrogen fixation from the atmosphere (Abril et al., 2005; Fürnkranz et al., 2008). Proteogenomic analyses of several phyllosphere microbial communities have revealed species that assimilate simple carbohydrates, amino acids and ammonium exudated by plants (Turner et al., 2013). On the other hand, ammonifiers and cellulose-degrading bacteria has been reported in the phyllosphere of woody plants (Abril et al., 2005), and nitrifiers were found in soybean leaves (Arias et al., 1999). A complex metabolic feedback between plants and phyllosphere communities may be occurring (Bringel and Couée, 2015) when the enzymatic activity of the microorganisms in the phyllosphere act as plant metabolites (Huang et al., 2014).

Nitrogen fixation is one of the most studied functions of the foliar microbiota (Abril et al., 2005; Daza et al., 2015). Klebsiella spp. and Beijerinckia spp. are common free-living nitrogen-fixing bacteria found in phyllosphere microbial communities (Morris, 2002). Furthermore, Beijerinckia spp. strains have increased rice yield, when compared between a Beijerinckia spp.inoculated field and one with conventional fertilizers (Morris, 2002). Similarly, Enterobacter radicincitans has been isolated from the phyllosphere of wheat (Ruppel et al., 2006) and promoted plant growth through nitrogen fixation and phytohormone production when inoculated in the soil (Almethyeb et al., 2013). On the other hand, Klebsiella spp. and various cyanobacteria were found in the phyllosphere of plants from a tropical forest in Costa Rica, related to high $\mathrm{N}_{2}$ fixation rates (Fürnkranz et al., 2008).

With respect to Actinobacteria class, Arthrobacter has been found to inhabit leaf surfaces (Rastogi et al., 2012). This bacteria genus can degrade aromatic hydrocarbons and pesticides (Scheublin and Leveau, 2013) and presents a high resistance to desiccation (Labeda et al., 1976). Thus, it could be a good choice for decreasing contamination by pesticides application (Turnbull et al., 2001).

\section{Biological control}

The use of biological control agents isolated from phyllosphere has been less exploited than those isolated from the soil or roots. However, there are biocontrol agents that have been successful in the treatment of some diseases associated with the phyllosphere (Fernando et al., 2007).

Interactions between phyllosphere bacteria could trigger changes in leaf transcriptome, suggesting molecular recognition by plants (Lemanceau et al., 2017). In this respect, the presence of the pathogen Xanthomonas campestri pv. vitians in lettuce is positively correlated to the presence of Alkanindiges, also reported in lettuce phyllosphere (Hunter et al., 2010), and negatively correlated with Bacillus, Erwinia and Pantoea, which act as antagonists (Rastogi et al., 2012). Pseudomonas syringae is an important pathogen found in the phyllosphere and can be controlled with Sphingomonas melonis because of the expression of pathogenesis-related proteins and antimicrobial proteins (Innerebner et al., 2011). Meanwhile, Pseudomonas fluorescens A506 reduces fire blight disease in pear and suppresses Erwinia amylovora growth in the phyllosphere through competition for nutrients and space (Wilson and Lindow, 1993). 
Furthermore, antagonistic activity from bacteria can reduce fungal pathogenicity in the phyllosphere (Griffin and Carson, 2015). For example, Pseudomonas spp. and Bacillus spp. can produce compounds, inducing systemic resistance responses in several plant species (Vorholt, 2012) and dramatically reducing fungal infection (Ceballos et al., 2012). Bacillus spp. are the most used biological control agents in agriculture. They have a broad spectrum of antagonistic activity (Huang et al., 2012), and several strains have been used as biocontrol agents in cacao (Melnick et al., 2008; Villamil et al., 2015), sugar beet (Collins et al., 2003), citrus (Huang et al., 2012), strawberry (Wei et al., 2016), cotton, rice and amaranth leaves (Wang et al., 2014). The ability to form endospore, produce secondary metabolites, proteins (Zhang et al., 2008), and antibiotics (Raaijmakers et al., 2002) and induce systemic resistance (Lahlali et al., 2013) has made Bacillius a widely used biocontrol agent for phyllosphere pathogens (Wei et al., 2016).

Recently, the use of native microorganisms as biocontrol agents has attracted special interest because of their special attributes (Kumar and Gopal, 2015; Cruz-Martín et al., 2016). They are adapted and established to local abiotic conditions or hosts and play a protecting role in the host plant against foreign pathogen microorganisms (Kumar and Gopal, 2015). For instance, representatives of the Bacillaceae family isolated from Mussa spp. phyllosphere showed antifungical activity against black Sigatoka disease ( $M y$ cosphaerella fijiensis) (Poveda et al., 2010; Cruz-Martín et al., 2016). Also, in Mussa spp., Salazar et al. (2006) found chitinolytic and glucanolytic activity against $M$. fijiensis by native bacteria.

On the other hand, changes in nutrient allocation towards leaf surfaces can manipulate the phyllosphere microbial community as a protection mechanism against pathogens (Manching et al., 2014). In crops, specific bacterial communities colonizing the phyllosphere have an important role protecting plants against pathogens (Williams et al., 2013; Manching et al., 2014). For instance, rice (Ren et al., 2014) and lettuce (Williams et al., 2013) seem to benefit from the Enterobacteriaceae group, increasing biomass production through pathogen suppression (Pusey et al., 2011) and nitrogen fixation (Feng et al., 2003).

Several studies on the phyllosphere microbiome have revealed a large number of novelties, which could be important for maintaining agriculture sustainability (Gupta and Bhargava, 2018), and more institutions are using their resources for the search for new products based on microorganisms. Patent processes found in the Patentscope database attached to WIPO-World Intellectual Property confirm that products based on microorganisms isolated from the phyllosphere can be used in agriculture.

a) Use of lactic acid bacteria associated with the phyllosphere as biocontrol agents to reduce the growth of pathogenic bacteria (McGarvey et al., 2017),

b) Microbial consortium for agricultural use and formulation (Suárez, et al., 2019),

c) Enterobacter sp. 3bh19 for preventing downy mildew. Application in cucumber phyllosphere (Luo et al., 2017),

d) Bacteria isolated from the phyllosphere promoting plant growth (Bai et al., 2014),

e) Novel Methylobacterium sp. CBMB 27 having an effect of promoting plant growth (Sa et al., 2012),

f) Bacteria degrading pyrethroid insecticide and method for preparing fungicide (Bai et al., 2008b),

h) Screening method for thermophilic bacteria isolated from the phyllosphere (Bai et al., 2008a).

\section{STUDIES OF PHYLLOSPHERE COMMUNITIES IN COLOMBIA}

Pathogenic microorganisms inhabit the phyllosphere of two important crops in Colombia: Xanthomonas axonopodis pv. Manihotis and M. fijiensis, are causal agents of bacterial blight in cassava (Manihot esculenta) (Restrepo et al., 2000) and black sigatoka in banana (Musa spp.) (Marín et al., 2003), respectively.

On the other hand, several examples of biological controls are known in Colombia. In Cundinamarca, Candida kunwinensis and Rhodotorula colostri were isolated from blackberry crops (Rubus glaucus), which presented antagonist activity against Botritys cinerea (Medina et al., 2009). In another study in Uraba, bacterial strains with antagonist activity against $M$. fijiensis were isolated from leaves of Mussa spp. They were identified as Bacillus subtibilis and B. amyloliquefaciens and decreased $M$. fijiensis infection by more than 90\% (Ceballos et al., 2012).

Taxonomical profiles of the phyllosphere in crops such as the cape gooseberry (Physalis peruviana) have been identified. Leaf surfaces of cape gooseberry crops in Boyacá showed a high abundance of 
bacteria Pseudomonas spp. and Enterobacter spp., followed the yeast Rhodotorula and fungi Capnodium, Cladosporium and Penicillium (Toloza and Lizarazo, 2014). Furthermore, in natural ecosystems such as Andean high-mountain, the phyllosphere microbial community associated with Espeletia plants in the Los Nevados Natural National Park was accessed to compare important microbial contributions to geobiological processes, as well as the potential in terms of bioprospecting for microbial processes such as bioremediation, nutrient acquisition, and antimicrobial compound production (Ruíz-Pérez et al., 2016).

\section{CONCLUSIONS AND FUTURE PERSPECTIVES}

Most of the studies on phyllosphere have focused on plant protection or antagonistic activity. A few have characterized nitrogen-fixing communities or plant growth-promoting bacteria in natural or agricultural systems. The phyllosphere is an environment that can harbor microorganisms linked to ecosystem functions, especially those involved with carbon and nitrogen cycles that are closely related to plant nutrition.
Research on foliar nutrition by microorganisms could expand our understanding of microbial mechanisms as a strategy to be applied in agriculture and used in the inoculation of soil microorganisms.

Characterizing the taxonomic and functional profiles of the microbial community, in addition to evaluating ecological interactions, identifies core groups and functions that can occur in different plant species in natural environments. In turn, the information obtained from studies on natural environments allows these profiles to be explored in plant species of horticultural interest in order to increase plant productivity.

Biotechnology offers great potential for applications of beneficial microorganisms in agriculture in order to increase plant productivity. Furthermore, it will help in understanding how the microbial community in the phyllosphere affects plant growth and health in agroecosystems. Bioprospecting the use of microorganisms associated with plants, in this case, the microbial community associated with the phyllosphere, is important as an alternative for fertilization and protection in horticultural crops (Fig. 2).

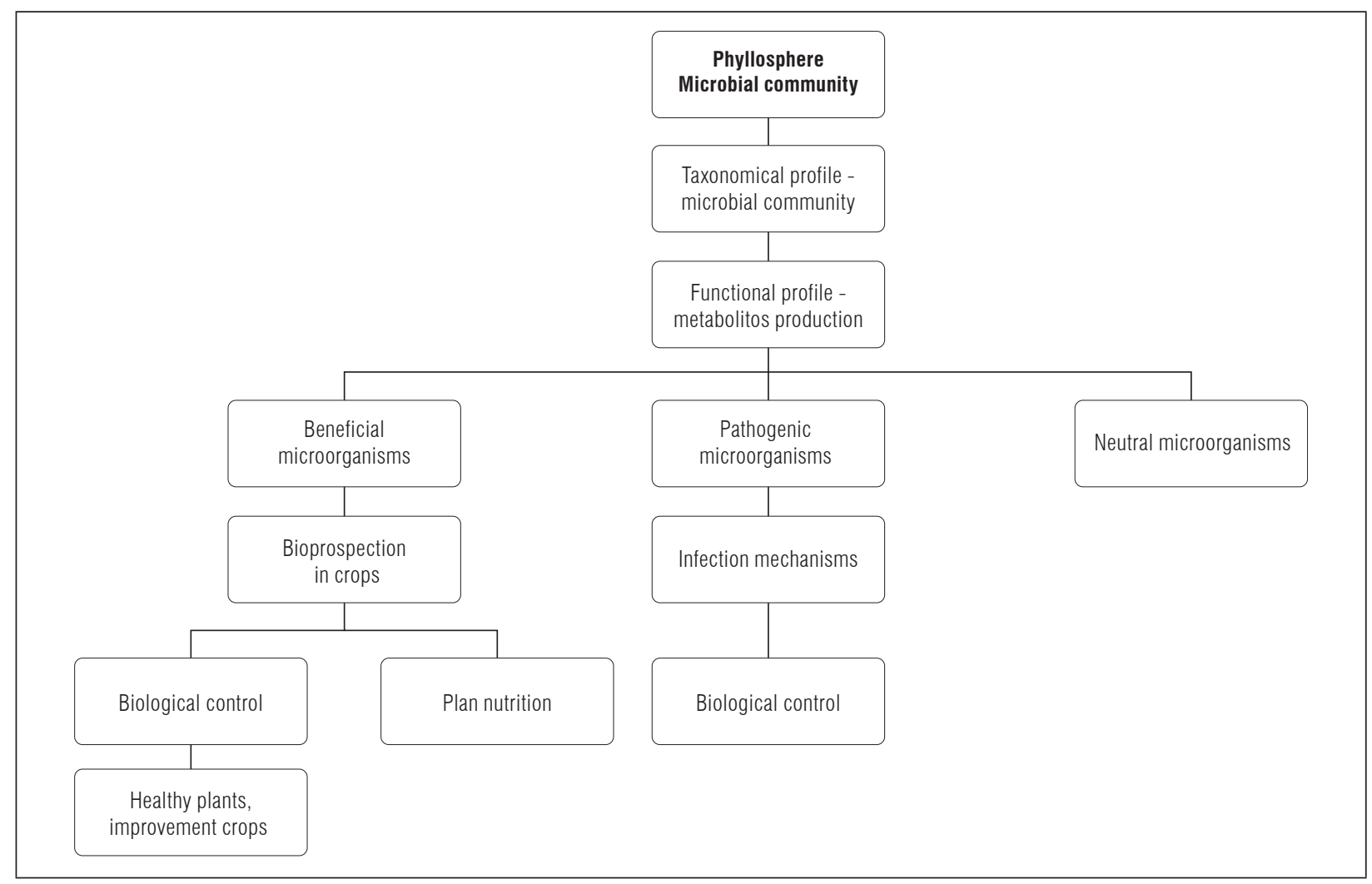

Figure 2. Fluxogram showing the more important characteristics in phyllosphere studies. 
Conflict of interest: this manuscript was prepared and reviewed with the participation of all authors, who declare that there exists no conflict of interest that that puts at risk the validity of the presented results.

\section{BIBLIOGRAPHIC REFERENCES}

Abril, A.B., P.A. Torres, and E.H. Bucher. 2005. The importance of phyllosphere microbial populations in nitrogen cycling in the Chaco semi-arid woodland. J. Trop. Ecol. 21, 103-107. Doi: 10.1017/S0266467404001981

Almethyeb, M., S. Ruppel, H.-M. Paulsen, N. Vassilev, and B. Eichler-Löbermann. 2013. Single and combined applications of arbuscular mycorrhizal fungi and Enterobacter radicincitans affect nutrient uptake of faba bean and soil biological characteristics. Landbauforschung Volkenrode 3(63), 229-234.

Adesemoye, A.O. and J.W. Kloepper. 2009. Plant-microbes interactions in enhanced fertilizer-use efficiency. Appl. Microbiol. Biotechnol. 85, 1-12. Doi: 10.1007/ s00253-009-2196-0

Andreote, F.D., T. Gumiere, and A. Durrer. 2014. Exploring interactions of plant microbiomes. Sci. Agric. 71(6), 528-539. Doi: 10.1590/0103-9016-2014-0195

Arias, R.S., M.A. Sagardoy, and J.W.L. Van Vuurde. 1999. Spatiotemporal distribution of naturally occurring Bacillus spp. and other bacteria on the phylloplane of soybean under field conditions. J. Basic Microbiol. 39(5-6), 283-292. Doi: 10.1002/(SICI)1521-4028(1999 12)39:5/6<283::AID-JOBM283>3.0.CO;2-G

Arnold, A.E., L.C. Mejía, D. Kyllo, E.I. Rojas, Z. Maynard, N. Robbins, and E.A. Herre. 2003. Fungal endophytes limit pathogen damage in a tropical tree. Proc. Natl. Acad. Sci. USA 100, 15649-15654. Doi: 10.1073/ pnas. 2533483100

Atamna-Ismaeel, N., O.M. Finkel, F. Glaser, I. Sharon, R. Schneider, A.F. Post, J.L. Spudich, C. von Mering, J.A. Vorholt, D. Iluz, O. Béjà, and S. Belkin. 2012a. Microbial rhodopsins on leaf surfaces of terrestrial plants. Environ. Microbiol. 14(1), 140-146. Doi: 10.1111/j.1462-2920.2011.02554.x

Atamna-Ismaeel, N., O. Finkel, F. Glaser, C. von Mering, J.A. Vorholt, M. Koblížek, S. Belkin, and O. Béjà. 2012. Bacterial anoxygenic photosynthesis on plant leaf surfaces. Environ. Microbiol. Rep. 4(2), 209-216. Doi: 10.1111/j.1758-2229.2011.00323.x

Bai, Z., L. Gu, M. Jing, L. Tang, H. Zhang, and G. Zhuang. 2008a. Pyrethroid insecticide degradation bacteria and method for preparing fungicide thereof. Patent CN101724576. Chine.

Bai, Z., Q. Zhang, J.Yang Q. Zhang, and G. Zhuang. 2008b. Screening method for plant phyllosphere thermophilic bacteria. Patent CN101724581. Chine.
Bai, Z., Q. Zhang, Y. Zhang, X. Pang, and G. Zhuang. 2014. Plant growth promoting bacteria separated from phyllosphere, and production method of bacterial agent of plant growth promoting bacteria. Patent CN105624056. Chine.

Baldoto, L.E.B. and L.F. Olivares. 2008. Phylloepiphytic interaction between bacteria and different plant species in a tropical agricultural system. Can. J. Microbiol. 54, 918-931. Doi: 10.1139/W08-087

Beattie, G.A. and S.E. Lindow. 1999. Bacterial colonization of leaves: a spectrum of strategies. Phytopathology 89(5), 353-359. Doi: 10.1094/PHYTO.1999.89.5.353

Berlec, A. 2012. Novel techniques and findings in the study of plant microbiota: search for plant probiotics. Plant Sci. 193-194, 96-102. Doi: 10.1016/j. plantsci.2012.05.010

Berry, D. and S. Widder. 2014. Deciphering microbial interactions and detecting keystone species with co-occurrence networks. Front. Microbiol. 5, 219. Doi: 10.3389/fmicb.2014.00219

Bhuvaneshwari, K. and P.K. Singh. 2015. Response of nitrogen-fixing water fern Azolla biofertilization to rice crop. 3 Biotech 5(4), 523-529. Doi: 10.1007/ s13205-014-0251-8

Bodenhausen, N., M. Bortfeld-Miller, M. Ackermann, and J.A. Vorholt 2014. A synthetic community approach reveals plant genotypes affecting the phyllosphere microbiota. PLoS Genet. 10, e1004283. Doi: 10.1371/ journal.pgen.1004283

Bodenhausen, N., M.W. Horton, and J. Bergelson. 2013. Bacterial communities associated with the leaves and the roots of Arabidopsis thaliana. PLoS One 8(2), e56329. Doi: 10.1371/journal.pone.0056329

Bokulich, N.A., J.H. Thorngate, P.M. Richardson, and D.A. Mills. 2014. Microbial biogeography of wine grapes is conditioned by cultivar, vintage, and climate. Proc. Natl. Acad. Sci. USA 111, 139-148. Doi: 10.1073/ pnas. 1317377110

Bringel, F. and I. Couée. 2015. Pivotal roles of phyllosphere microorganisms at the interface between plant functioning and atmospheric trace gas dynamics. Front. Microbiol. 6, 486. Doi: 10.3389/fmicb.2015.00486

Bulgarelli, D., K. Schlaeppi, S. Spaepen, E.L. Themaat, and P. Schulze-Lefert. 2013. Structure and functions of the bacterial microbiota of plants. Ann. Rev. Plant Biol. 64, 807-838. Doi: 10.1146/ annurev-arplant-050312-120106

Carter, M.Q., K. Xue, M.T. Brandl, F. Liu, L. Wu, J.W. Louie, R.E. Mandrell, and J. Zhou. 2012. Functional metagenomics of Escherichia coli O157: H7 interactions with spinach indigenous microorganisms during biofilm formation. PLoS One 7(9), e44186. Doi: 10.1371/journal.pone.0044186

Ceballos, I., S. Mosquera, M. Angulo, J.J. Mira, L.E. Argel, D. Uribe-Velez, M. Romez-Tabarez, S. Orduz-Peralta, and V. Villegas. 2012. Cultivable bacteria populations 
associated with leaves of banana and plantain plants and their antagonistic activity against Mycosphaerella fijiensis. Microbial. Ecol. 64, 641-653. Doi: 10.1007/ s00248-012-0052-8

Chelle, M. 2005. Phylloclimate or the climate perceived by individual plant organs: What is it? How to model it? What for? New Phytol. 166(3), 781-790. Doi: 10.1111/j.1469-8137.2005.01350.x

Collins, D.P., B.J. Jacobsen, and B. Maxwell. 2003. Spatial and temporal population dynamics of a phyllosphere colonizing Bacillus subtilis biological control agent of sugar beet cercospora leaf spot. Biol. Control 26(3), 224-232. Doi: 10.1016/S1049-9644(02)00146-9

Copeland, J.K., L. Yuan, M. Layeghifard, P.W. Wang, and D.S. Guttman. 2015. Seasonal community succession of the phyllosphere microbiome. Mol. Plant Microbe Interact. 28(3), 274-285. Doi: 10.1094/ MPMI-10-14-0331-FI

Cordier, T., C. Robin, X. Capdevielle, M.L. Desprez-Loustau, and C. Vacher. 2012. Spatial variability of phyllosphere fungal assemblages: genetic distance predominates over geographic distance in a European beech stand (Gaguus sylvatica). Fungal Ecol. 5, 509-520. Doi: 10.1016/j.funeco.2011.12.004

Cruz-Martín, M., M. Acosta-Suárez, B. Roque, T. Pichardo, R. Castro, and Y. Alvarado-Capó. 2016. Diversidad de cepas bacterianas de la filosfera de Musa spp. con actividad antifúngica frente a Mycosphaerella fijiensis Morelet. Biotec. Vegetal 16(1), 53-61.

Daza, M., J. Díaz, E. Aguirre, and N. Urrutia. 2015. Efecto de abonos de liberación lenta en la lixiviación de nitratos y nutrición nitrogenada en estevia. Rev. Colomb. Cienc. Hortíc. 9(1), 112-123. Doi: 10.17584/ rcch.2015v9i1.3750

Delmotte, N., C. Knief, S. Chaffron, G. Innerebner, B. Roschitzki, R. Schlapbach, C. von Mering, and J.A. Vorholt. 2009. Community proteogenomics reveals insights into the physiology of phyllosphere bacteria. Proc. Natl. Acad. Sci. USA 106, 16428-16433. Doi: 10.1073/pnas.0905240106

Dutta, C. and S. Paul. 2012. Microbial lifestyle and genome signatures. Curr. Genom. 13(2), 153-162. Doi: 10.2174/138920212799860698

Feng, Y.J., D.L. Shen, X.Z. Dong, and W. Song. 2003. In vitro symplasmata formation in the rice diazotrophic endophyte Pantoea agglomerans YS19. Plant Soil. 255, 435-444. Doi: 10.1023/A:1026079203474

Fernando, W.G.D., R. Ramarathnam, and T. de Kievit. 2007. Bacterial weapons of fungal destruction: Phyllosphere-targeted biological controlo of plant disease, with emphasis on sclerotinia stem rot and blackleg diseases in canola (Brassica napus L.). pp. 189-199. In: Kubicek, C.P. and I.S. Druzhinina (eds.). Environmental and microbial relationships. The Mycota 4. Springer, Berlin. Doi: 10.1007/978-3-540-71840-6_11
Finkel, O.M., A.Y. Burch, T. Elad, S.M. Huse, S.E. Lindow, A.F. Post, and S. Belkin. 2012. Distance-decay relationships partially determine diversity patterns of phyllosphere bacteria on Tamarix trees across the Sonoran Desert. Appl. Environ. Microbiol. 78(17), 61876193. Doi: 10.1128/AEM.00888-12

Finkel, O.M., A.Y. Burch, S.E. Lindow, A.F. Post, and S. Belkin. 2011. Geographical location determines the population structure in phyllosphere microbial communities of a salt-excreting desert tree. Appl. Environ. Microbiol. 77(21), 7647-7655. Doi: 10.1128/ AEM.05565-11

Finkel, O.M., T.O. Delmont, A.F. Post, and S. Belkin. 2016. Metagenomic signatures of bacterial adaptations to life in the phyllosphere of a salt-secreting desert tree. Appl. Environ. Microbiol. 82(9), 2854-2861. Doi: 10.1128/AEM.00483-16

Friesen, M.L., S.S. Porter, S.C. Stark, E.J. von Wettberg, J.L. Sachs, and E. Martinez-Romero. 2011. Microbially mediated plant functional traits. Ann. Rev. Ecol. Evol. Syst. 42, 23-46. Doi: 10.1146/ annurev-ecolsys-102710-145039

Fürnkranz, M., W. Wanek, A. Richter, G. Abell, F. Rasche, and A. Sessitsch. 2008. Nitrogen fixation by phyllosphere bacteria associated with higher plants and their colonizing epiphytes of a tropical lowland rainforest of Costa Rica. Isme J. 2, 561-570. Doi: 10.1038/ ismej.2008.14

Griffin, E.A. and W.P. Carson. 2015. The ecology and natural history of foliar bacteria focus on tropical forest and agroecosystems. Bot. Rev. 81, 105-149. Doi: 10.1007/s12229-015-9151-9

Gupta, N., S. Vats, and P. Bhargava. 2018. Sustainable agriculture: role of metagenomics and metabolomics in exploring the soil microbiota. pp. 183-199. In: Choudhary, D., M. Kumar, R. Prasad, and V. Kumar (eds). Silico approach for sustainable agriculture. Springer, Singapore. Doi: 10.1007/978-981-13-0347-0_11

Huang, T.-P., D.D.-S. Tzeng, A.C.L. Wong, C.-H. Chen, K.M. Lu, Y.-H. Lee, W.-D. Huang, B.-F. Hwang, and K.C. Tzeng. 2012. DNA polymorphisms and biocontrol of Bacillus antagonistic to citrus bacterial canker with indication of the interference of phyllosphere biofilms. PLoS One 7(7), e42124. Doi: 10.1371/journal. pone.0042124

Huang, S.H., J.Y. Zhang, Z. Tao, L. Lei, Y.H. Yu, and L.Q. Huang. 2014. Enzymatic conversion from pyridoxal to pyridoxine caused by microorganisms within tobacco phyllosphere. Plant Physiol. Biochem. 85, 9-13. Doi: $10.1016 /$ j.plaphy.2014.10.006

Hunter, P.J., P. Hand, D. Pink, J.M. Whipps, and G.D. Bending. 2010. Both leaf properties and microbe-microbe interactions influence within-species variation in bacterial population diversity and structure in the lettuce (Lactuca Species) phyllosphere. Appl. Environ. Microbiol. 76(24), 8117-8125. Doi: 10.1128/AEM.01321-10 
Igiehon, N.O. and O.O. Babalola. 2017. Biofertilizers and sustainable agricultura: exploring arbuscular mycorrhizal fungi. Appl. Microb. Biotech. 101(12), 48714881. Doi: 10.1007/s00253-017-8344-z

Innerebner, G., C. Knief, and J.A. Vorholt. 2011. Protection of Arabidopsis thaliana against leaf-pathogenic Pseudomonas syringae by Sphingomonas strains in a controlled model system. Appl. Environ. Microbiol. 77, 32023210. Doi: 10.1128/AEM.00133-11

Jackson, C.R. and W.C. Denney. 2011. Annual and seasonal variation in the phyllosphere bacterial community associated with leaves of the southern magnolia (Magnolia grandiflora). Microb. Ecol. 61, 113-122. Doi: 10.1007/s00248-010-9742-2

Jumpponen, A. and K.L. Jones. 2009. Massively parallel 454 sequencing indicates hyperdiverse fungal communities in temperate Quercus macrocarpa phyllosphere. New Phytol. 184(2), 438-448. Doi: j.1469-8137.2009.02990.x

Kembel, S.W., T.K.O. Connor, H.K. Arnold, S.P. Hubbell, and S.J. Wright. 2014. Relationships between phyllosphere bacterial communities and plant functional traits in a neotropical forest. Proc. Natl. Acad. Sci. USA 38, 13715-13720. Doi: 10.1073/pnas.1216057111

Kembel, S.W. and R.C. Mueller. 2014. Plant traits and taxonomy drive host associations in tropical phyllosphere fungal communities. Botany 92, 303-311. Doi: 10.1139/cjb-2013-0194

Kim, M., D. Singh, A. Lai-hoe, R. Go, R.A. Rahim, A.N. Ainuddin, J. Chun, and J.M. Adams. 2012. Distinctive phyllosphere bacterial communities in tropical trees. Microb. Ecol. 63, 674-681. Doi: 10.1007/ s00248-011-9953-1

Knief, C., N. Delmotte, S. Chaffron, M. Stark, G. Innerebner, R. Wassmann, C. von Mering, J.A. and Vorholt. 2012. Metaproteogenomic analysis of microbial communities in the phyllosphere and rhizosphere of rice. ISME J. 6, 1378-1390. Doi: 10.1038/ismej.2011.192

Knief, C., L. Frances, and J.A. Vorholt. 2010. Competitiveness of diverse Methylobacterium strains in the phyllosphere of Arabidopsis thaliana and identification of representative models, including $M$. extorquens PA1. Microb. Ecol. 60, 440-452. Doi: 10.1007/ s00248-010-9725-3

Kumar, B.L. and D.V.R.S. Gopal. 2015. Effective role of indigenous microorganisms for sustainable environment. 3 Biotech. 5(6), 867-876. Doi: 10.1007/ s13205-015-0293-6

Labeda, D.P., K.C. Liu, and L.E. Casida. 1976. Colonization of soil by Arthrobacter and Pseudomonas under varying conditions of water and nutrient availability as studied by plate counts and transmission electron microscopy. Appl. Environ. Microbiol. 31, 551-561. Doi: 10.1128/AEM.31.4.551-561.1976

Laforest-Lapointe, F., C. Messier, and S. Kembel. 2016. Tree phyllosphere bacterial communities: exploring the magnitude of intra- and inter-individual variation among host species. PeerJ. 4, e2367. Doi: 10.7717/ peerj.2367

Lahlali, R., G. Peng, B.D. Gossen, L. McGregor, F.Q. Yu, R.K. Hynes, S.F. Hwang, M.R. McDonald, and S.M. Boyetchko. 2013. Evidence that the biofungicide serenade (Bacillus subtilis) suppresses clubroot on canola via antibiosis and induced host resistance. Phytopathology 103, 245-254. Doi: 10.1094/PHYTO-06-12-0123-R

Lambais, M.R. S.E. Barrera, E.C. Santos, D.E. Crowley, and A. Jumpponen. 2017. Phyllosphere metaproteomes of trees from the Brazilian atlantic forest show high levels of functional redundancy. Microb. Ecol. 73, 123134. Doi: 10.1007/s00248-016-0878-6

Lambais, M.R., D.E. Crowley, J.C. Cury, R.C. Bull, and R.R. Rodrigues. 2006. Bacterial diversity in tree canopies of the Atlantic forest. Science 312(5782), 1917. Doi: 10.1126/science.1124696

Lambais, M.R., A.R. Lucheta, and D.E. Crowley. 2014. Bacterial community assemblages associated with the phyllosphere, dermosphere, and rhizosphere of tree species of the atlantic forest are host taxon dependent. Microb. Ecol. 68(3), 567-574. Doi: 10.1007/ s00248-014-0433-2

Lemanceau, P., M. Barret, S. Mazurier, S. Mondy, B. Pivato, T. Fort, and C. Vacher. 2017. Plant communication with associated microbiota in the spermosphere, rhizosphere and phyllosphere. pp. 101-133. In: Becard, G. (ed.). Advances in botanical research. How plants communicate with their biotic environment. Vol. 82. Academic Press, London. Doi: 10.1016/bs.abr.2016.10.007

Lindow, S.E. and M.T. Brandl. 2003. Microbiology of the phyllosphere. Appl. Environ. Microbiol. 69, 18751883. Doi: 10.1128/AEM.69.4.1875-1883.2003

Luo, Y., L. Zhang, W. Yang, L. Zheng. 2017. Enterobacter sp. 3bh19 for preventing downy mildew by improving phyllosphere micro-ecology of cucumbers and application of enterobacter sp.3bh19. Patent CN106834180. Chine.

McGarvey, J.A., R.M. Hnasko, L.H. Stanker, and L.A. Gorski. 2017. Use of phyllosphere associated lactic acid bacteria as biocontrol agents to reduce bacterial growth on fresh produce. Patent WO2017116856. Washington, DC.

Manching, H.C., P.J. Balint-Kurti, and A.E. Stapleton. 2014. Southern leaf blight disease severity is correlated with decreased maize leaf epiphytic bacterial species richness and the phyllosphere bacterial diversity decline is enhanced by nitrogen fertilization. Front. Plant Sci. 5, 403. Doi: 10.3389/fpls.2014.00403

Marín, D.H., A.R. Ronald, M. Guzman, and T.B. Sutton. 2003. Black sigatoka: an increasing threat to banana cultivation. Plant Dis. 87, 208-219. Doi: 10.1094/ PDIS.2003.87.3.208

Medina, C., D. Cristancho, and D. Uribe. 2009. Respuesta fisiológica y capacidad antagonista de aislamientos 
filosféricos de levaduras obtenidos en cultivos de mora (Rubus glaucus). Acta Biol. Colomb. 14(3), 181-196.

Melnick, R.L., N.K. Zidack, B.A. Bailey, N.S. Maximova, M. Guiltinan, and P.A. Backman. 2008. Bacterial endophytes: Bacillus spp. from annual crops as potential biological control agents of black pod rot of cacao. Biol. Control 46, 46-56. Doi: 10.1016/j. biocontrol.2008.01.022

Mercier, J. and S.E. Lindow. 2000. Role of leaf surface sugars in colonization of plants by bacterial epiphytes. Appl. Environ. Microbiol. 66(1), 369-374. Doi: 10.1128/ AEM.66.1.369-374.2000

Morris, C.E. 2002. Phyllosphere. In: eLS. Doi: 10.1038/npg. els.0000400

Müller, T. and S. Ruppel. 2014. Progress in cultivation-independent phyllosphere microbiology. FEMS Microbiol. Ecol. 87, 2-17. Doi: 10.1111/1574-6941.12198

Müller, D.B., C. Vogel, Y. Bai, and J.A. Vorholt. 2016a. The plant microbiota: systems-level insights and perspectives. Ann. Rev. Genet. 50, 9.1-9.24. Doi: 10.1146/ annurev-genet-120215-034952

Müller, D.B., O.T. Schubert, H. Rost, R. Aebersold, and J.A. Vorholt. 2016b. Systems-level proteomics of two ubiquitous leaf commensals reveals complementary adaptive traits for phyllosphere colonization. Mol. Cell. Proteom. 15(10), 3256-3269. Doi: 10.1074/mcp. M116.058164

Mus, F., M.B. Crook, K. Garcia, A. Garcia-Costas, B.A. Geddes, E.D. Kouri, P. Paramasivan, M.-H. Ryu, G.E.D. Oldroyd, P.S. Poole, M.K. Udvardi, C.A. Voigt, J-M. Ané, and J.W. Peters. 2016. Symbiotic nitrogen fixation and the challenges to its extension to non-legumes. Appl. Environ. Microbiol. 82, 3698-3710. Doi: 10.1128/ AEM.01055-16

Ottesen, A.R., A. González, J.R. White, J.B. Pettengi11, C. Li, S. Allard, S. Rideout, M. Allard, T. Thomas Hill, P. Evans, E. Strain, S. Musser, R. Knight, and E. Brown. 2013. Baseline survey of the anatomical microbial ecology of an important food plant: Solanum lycopersicum (tomato). BMC Microbiol. 13, 114. Doi: 10.1186/1471-2180-13-114

Peñuelas, J. and J. Terradas. 2014. The foliar microbiome. Trends Plant Sci. 19(5), 278-280. Doi: 10.1016/j. tplants.2013.12.007

Poudel, R., A. Jumponnen, D.C. Schlatter, T.C. Paulitz, B.B. McSpadden Gardener, L.L. Kinkel, and K.A. Garrett. 2016. Microbiome networks: a systems framework for identifying candidate microbial assemblages for disease management. Anal. Theor. Plant pathol. 106, 10831096. Doi: 10.1094/PHYTO-02-16-0058-FI

Poveda, I., M. Cruz-Martín, C. Sánchez-García, M. Acosta-Suárez, M. Leiva-Mora, B. Roque, and Y. Alvarado-Capó. 2010. Caracterización de cepas bacterianas aisladas de la filosfera de Musa spp. con actividad antifúngica in vitro frente a Mycosphaerella fijiensis. Biotec. Vegetal 10(1), 57-61.
Prussin II, A.J. and L.C. Marr. 2015. Sources of airborne microorganisms in the built environment. Microbiome 3, 78. Doi: 10.1186/s40168-015-0144-z

Pusey, P.L., V.O. Stockwell, C.L. Reardon, T.H.M. Smits, and B. Duffy. 2011. Antibiosis activity of Pantoea agglomerans biocontrol strain E325 against Erwinia amylovora on apple flower stigmas. Phytopathology 101(10), 1234-1241. Doi: 10.1094/PHYTO-09-10-0253

Raaijmakers, J.M., M. Vlami, and J.T. de Souza. 2002. Antibiotic production by bacterial biocontrol agents. Anton. Leeuw. Int. 81, 537-547. Doi: 10.1023/A:1020501420831

Rastogi, G., G.L. Coaker, and J.H. Leveau. 2013. New insights into the structure and function of phyllosphere microbiota through high-throughput molecular approaches. FEMS Microbiol. Lett. 348, 1-10. Doi: 10.1111/1574-6968.12225

Rastogi, G., A. Sbodio, J.J. Tech, T.V. Suslow, G.L. Coaker, and J.H. Leveau. 2012. Leaf microbiota in an agroecosystem: spatiotemporal variation in bacterial community composition on field-grown lettuce. Isme J. 6, 1812-1822. Doi: 10.1038/ismej.2012.32

Redford, A.J., R.M. Bowers, R. Knight, Y. Linhardt, and N. Fierer. 2010. The ecology of the phyllosphere: geographic and phylogenetic variability in the distribution of bacteria on tree leaves. Environ. Microbiol. 12, 28852893. Doi: 10.1111/j.1462-2920.2010.02258.x

Redford, A.J. and N. Fierer. 2009. Bacterial succession on the leaf surface: a novel system for studying successional dynamics. Microb. Ecol. 58, 189-198. Doi: 10.1007/ s00248-009-9495-y

Remus-Emsermann, M.N. and R.O. Schlechter. 2018. Phyllosphere microbiology: at the interface between microbial individuals and the plant host. New Phytol. 218(4), 1327-1333. Doi: 10.1111/nph.15054

Remus-Emsermann, M.N.P. and J.A. Vorhold. 2014. Complexities of microbial life on leaf surfaces. Microbe 9(11), 448-452. Doi: 10.1128/microbe.9.448.1

Ren, G., H. Zhang, X. Lin, J. Zhu, and Z. Jia. 2014. Response of phyllosphere bacterial communities to elevated $\mathrm{CO}_{2}$ during rice growing season. Appl. Microbiol. Biotech. 98, 9459-9471. Doi: 10.1007/s00253-014-5915-0

Restrepo, S., M.C. Duque, and V. Verdier. 2000. Characterization of pathotypes among isolates of Xanthomonas axonopodis pv. manihotis in Colombia. Plant Pathol. 49, 680-687. Doi: 10.1046/j.1365-3059.2000.00513.x

Rosenberg, E. and I. Zilber-Rosenberg. 2016. Microbes drive evolution of animals and plants: the hologenome concept. mBio 7(2), e01395-15. Doi: 10.1128/ mBio.01395-15

Ruíz-Perez, C., S. Restrepo, and M.M. Zambrano. 2016. Microbial and functional diversity within the phyllosphere of Espeletia species in an Andean High-Mountain ecosystem. Appl. Environ. Microbiol. 82(6), 1807-1817. Doi: 10.1128/AEM.02781-15 
Ruppel, S., J. Rühlmann, and W. Merbach. 2006. Quantification and localization of bacteria in plant tissues using quantitative real-time PCR and online emission fingerprinting. Plant Soil 286, 21-35. Doi: 10.1007/ s11104-006-9023-5

Sa, T.-M., M. Munusamy, W.J. Yim, M.K. Lee, and I.S. Hong. 2012. Novel Methylobacterium sp. microorganism phyllosphaerae cbmb 27 having an effect of promoting plant growth. Patent KR1020100121716. Korea.

Salazar, L.M., L.F. Patiño, and E. Bustamante. 2006. Sustratos foliares para el incremento de bacterias quitinolíticas y glucanolíticas en la filosfera de banano banano. Rev. Fac. Nac. Agron. Medellín 59(2), 3449-3465.

Scheublin, T.R. and J.H. Leveau. 2013. Isolation of Arthrobacter species from the phyllosphere and demonstration of their epiphytic fitness. Microbiol Open. 2, 205-213. Doi: 10.1002/mbo3.59

Schlechter, R.O., M. Miebach, and M.N. Remus-Emsermann. 2019. Driving factors of epiphytic bacterial communities: a mini-review. J. Adv. Res. 19, 57-65. Doi: 10.1016/j.jare.2019.03.003

Suárez, R.J.A. and R. Mehta. 2019. Microbial consortium for agricultural use and formulation containing same. Patent WO2019098817. Mexico.

Toloza, D.L. and L.M. Lizarazo. 2014. Poblaciones microbianas asociadas a la rizósfera y filósfera de plantas de uchuva (Physalis peruviana L.). Rev. Cien. 18(2), 27-38. Doi: 10.25100/rc.v18i2.6092

Turnbull, G.A., M. Ousley, A. Walker, E. Shaw, and J.A.W. Morgan. 2001. Degradation of substituted phenylurea herbicides by Arthrobacter globiformis Strain D47 and Characterization of a plasmid-associated hydrolase gene, puhA. Appl. Environ. Microbiol. 67(5), 22702275. Doi: 10.1128/AEM.67.5.2270-2275.2001

Turner, T.R., E.K. James, and P.S. Poole. 2013. The plant microbiome. Genome Biol. 14(6), 209. Doi: 10.1186/ gb-2013-14-6-209

Vacher, C., A. Hampe, A.J. Porté, U. Sauer, S. Compant, and C.E. Morris. 2016. The phyllosphere: Microbial jungle at the plant-climate interface. Ann. Rev. Ecol. Evol. Sys. 47,1-24. Doi: 10.1146/annurev-ecolsys-121415-032238

Villamil, J.E., S.E. Viteri, and W. Villegas. 2015. Aplicación de antagonistas microbianos para el control biológico de Moniliophthora roreri Cif \& Par. en Theobroma cacao L. bajo condiciones de campo. Rev. Fac. Nac. Agron. Medellín 68(1), 7441-7450. Doi: 10.15446/rfnam. v68n1.47830

Vogel, C., N. Bodenhausen, W. Gruissem, and J.A. Vorholt. 2016. The Arabidopsis leaf transcriptome reveals distinct but also overlapping responses to colonization by phyllosphere commensals and pathogen infection with impact on plant health. New Phytol. 212, 192-207. Doi: 10.1111/nph.14036

Vorholt, J. 2012. Microbial life in the phyllosphere. Nature Rev. Microbiol. 10, 828-840. Doi: 10.1038/ nrmicro2910

Wang, X., Y. Xue, M. Han, Y. Bu, and C. Liu. 2014. The ecological roles of Bacillus thuringiensis within phyllosphere environments. Chemosphere 108, 258-264. Doi: 10.1016/j.chemosphere.2014.01.050

Wei, F., X. Hu, and X. Xu. 2016. Dispersal of Bacillus subtilis and its effect on strawberry phyllosphere microbiota under open field and protection conditions. Sc. Rep. 6 , 22611. Doi: 10.1038/srep22611

Whipps, J.M., P. Hand, D. Pink, and G.D. Bending. 2008. Phyllosphere microbiology with special reference to diversity and plant genotype. J. Appl. Microbiol. 105, 1744-1755. Doi: 10.1111/j.1365-2672.2008.03906.x

Williams, T.R., A.L. Moyne, L.J. Harris, and M.L. Marco. 2013. Season, irrigation, leaf age, and Escherichia coli inoculation influence the bacterial diversity in the lettuce phyllosphere. PLoS One 8(7), e68642. Doi: 10.1371/journal.pone.0068642

Wilson, M. and S.E. Lindow. 1993. Interactions between the biological control agent Pseudomonas fluorescens A506 and Erwinia amylovora in pear blossoms. Acta Hortic. 338, 329-330. Doi: 10.17660/ActaHortic.1993.338.51

Wright, I.J., P.B. Reich, M. Westoby, D.D. Ackerly, Z. Baruch, F. Bongers, J. Cavender-Bares, T. Chapin, J.H.C. Cornelissen, M. Diemer, J. Flexas, E. Garnier, P.K. Groom, J. Gulias, K. Hikosaka, B.B. Lamont, T. Lee, W. Lee, C. Lusk, J.J. Midgley, M.-L. Navas, Ü. Niinemets, J. Oleksyn, N. Osada, H. Poorter, P. Poot, L. Prior, V.I. Pyankov, C. Roumet, S.C. Thomas, M.G. Tjoelker, E.J. Veneklaas, and R. Villar. 2004. The worldwide leaf economics spectrum. Nature 428, 821-827. Doi: 10.1038 /nature02403

Yadav, R.K.P., K. Karamanoli, and D. Vokou. 2011. Bacterial populations on the phyllosphere of Mediterranean plants: influence of leaf age and leaf surface. Front. Agric. China. 5, 60-63. Doi: 10.1007/ s11703-011-1068-4

Zhang, B., Z. Bai, D. Hoefel, L. Tang, Z. Yang, G. Zhuang, J. Yang, and H. Zhang. 2008. Assessing the impact of the biological control agent Bacillus thuringiensis on the indigenous microbial community within the pepper plant phyllosphere. FEMS Microbiol. Lett. 284, 102-108. Doi: 10.1111/j.1574-6968.2008.01178.x 